This is a preprint version of the following published document:

Wirkner, M., Weis, S., San Miguel, V., Álvarez, M., Gropeanu, R. A., Salierno, M., Sartoris, A., Unger, R. E., Kirkpatrick, C. J. \& del Campo, A. (2011): Photoactivatable caged cyclic RGD peptide for triggering integrin binding and cell adhesion to surfaces. ChemBioChem, 12 (17), pp. 2623-2629.

DOI: $10.1002 /$ cbic.201100437

(C) WILEY-VCH Verlag GmbH \& Co. KGaA, Weinheim, 2011 


\title{
Photoactivatable caged cyclic RGD peptide for triggering integrin binding and cell adhesion to surfaces
}

\author{
Melanie Wirkner ${ }^{(1)}$, Simone Weis ${ }^{(1)}$, Dr. Verónica San Miguel, ${ }^{(1)}$ Dr. Marta Álvarez ${ }^{(1)}$, Dr. \\ Radu A. Gropeanu ${ }^{(1)}$, Dr. Marcelo Salierno ${ }^{(1)}$, Anne Sartoris ${ }^{(2)}$, Dr. Ronald E. Unger ${ }^{(2)}$, Prof. \\ C. James Kirkpatrick ${ }^{(2)}$, Dr. Aránzazu del Campo ${ }^{(1)} *$ \\ ${ }^{(1)}$ Max-Planck-Institut für Polymerforschung, Ackermannweg 10, 55128 Mainz, Germany \\ (2) Institute of Pathology, University Medical Center of the Johannes Gutenberg University \\ Mainz, Langenbeckstrasse 1, 55101 Mainz, Germany \\ *contact : e-mail: delcampo@ mpip-mainz.mpg.de \\ Tel: +496131379563 \\ Fax +496131379271
}

Keywords: interfaces, photochemistry, caged RGD, cell adhesion, cell patterns

\begin{abstract}
We report on the synthesis and properties of a photoactivatable caged RGD peptide and its application for phototriggering integrin and cell binding to surfaces. We analyzed in detail (i) the differences in the integrin binding affinity of the caged and uncaged forms via quartz crystal microbalance (QCM) studies, (ii) the efficiency and yield of the photolytic uncaging reaction, (iii) the biocompatibility of the photolysis byproducts and irradiation conditions and (iv) the possibility of site, temporal and density control of integrin binding and, therefore, human cell attachment, (v) the possibility of in situ generation of cell patterns and cell gradients by controlling the exposure. These studies provide a clear picture of the potential and limitations of caged ligands for integrin-mediated cell adhesion and demonstrate the application of this approach to control and study other types of cell interactions and response.
\end{abstract}

\section{Introduction}

Controlled and selective adhesion and release of cells to surfaces is an important issue for any progress in cell biology and tissue engineering. Different strategies have been reported that use thermally, ${ }^{1}$ electrochemically ${ }^{2}$ or photochemically ${ }^{3}$ responsive surfaces to manipulate cell 
attachment and detachment (see reference ${ }^{4}$ for a recent review). Among the possible cellfriendly stimuli, light-based systems are the ones that have demonstrated the most accurate spatiotemporal control of cellular response and flexibility in terms of material of use.

Reported photochemical approaches to trigger cell adhesion rely on a light-triggered exposure of cell adhesive peptides at the surface (usually RGD $^{5}$ able to be recognized by integrins at the cell membrane) via (i) a phase transition of RGD-containing amphiphilic peptides, ${ }^{3 \mathrm{c}}$ (ii) photoisomerization of azobenzene linkers units linking the RGD peptide to the surface, ${ }^{3 \mathrm{~d}-\mathrm{f}}$ or (iii) photocleavage of protecting groups (cages) directly attached to the surface immobilized RGD structure. ${ }^{3 a, b}$ Reported light-based strategies to trigger cell detachment include photodegradable gels ${ }^{6}$ and photocleavable linkers that detach RGD ligands (to which cells attach) from the surface of the material upon light exposure. Amongst these strategies, photocleavable caging groups ${ }^{3 \mathrm{a}, \mathrm{b}, 7}$ are the only ones that are not material-specific, allow dynamic variation and precise tuning of the stimulus over time, and provide direct control over the molecular interactions at the binding site.

We have reported a photolabile cyclo[RGD(DMNPB)fK] (Figure 1) which is a derivative of cyclo[RGDfK $]^{5}$ containing a 3-(4,5-dimethoxy-2-nitrophenyl)-2-butyl ester (DMNPB) photolabile group at the $\mathrm{COOH}$ group of the aspartate unit. ${ }^{3 \mathrm{~b}}$ This position acts as a ligand for one of the two bivalent cations involved in the RGD-integrin integrin $\alpha_{V} \beta_{3}$ binding site. $^{8}$ PEGylated surfaces modified with cyclo[RGD(DMNPB)fK] did not promote cell adhesion. Upon light-exposure, the DMNPB group was cleaved from the peptide and cell adhesion occurred. This peptide was used to phototrigger attachment of mouse fibroblast 3T3 cells to cell-repellent surfaces. In a similar approach, a caged linear peptide YAVTGRGDSPASS with an $o$-nitrobenzyl group introduced at the amide between the Gly and Arg residues has also demonstrated the ability to phototrigger attachment of HeLa cells. ${ }^{3 a}$ However, apart from impressive proof-of-principle results, ${ }^{3 a, b, 7}$ no studies have been reported analysing the physico-chemical and biological properties of the photosensitive caged RGDs. In this manuscript, we report a detailed study of the properties of cyclo[RGD(DMNPB)fK] as cell adhesion phototrigger including (i) the differences in the integrin binding affinity of the caged and uncaged forms via quartz crystal microbalance (QCM) studies, (ii) the efficiency of the photolytic uncaging reaction, (iii) the human cell biocompatibility of the photolysis byproducts and irradiation conditions and (iv) the possibility of site, temporal and density control of integrin binding and, therefore, cell attachment. The possibility of in situ generation of cell patterns and cell gradients by controlling the exposure dose will also be demonstrated. 
These studies provide a clear picture of the potential and limitations of caged ligands for integrin-mediated cell adhesion and should stimulate the application of this approach to control and study other kind of cell interactions and response.

\section{Experimental}

Cyclo[RGD(DMNPB)fK] was synthesized using an improved version of the previously reported protocol ${ }^{3 \mathrm{~b}}$ that is included as supporting information. The synthesis and characterisation of the DMNPB-caged silane for the photolysis studies of surface-bound chromophore is also included as supporting information.

Cleaning of substrates: Glass slides were cleaned by soaking in Piranha solution $\left(\mathrm{H}_{2} \mathrm{SO}_{4}\right.$ (conc.) $/ \mathrm{H}_{2} \mathrm{O}_{2}(30 \%)$ 5/1) for one night, rinsing with Milli-Q water, absolute ethanol and dried with a $\mathrm{N}_{2}$ stream. Gold-coated substrates for cell experiments were prepared by sequential deposition of chromium (20 ̊) and gold (200 $⿱$ ) films onto clean glass slides of round shape (diameter $12 \mathrm{~mm}$ ) via a thermal evaporator (Edward FL 400, 5 x 10-6 mbar, $2 \AA / \mathrm{s}$ ).

RGD functionalised self-assembled monolayers (SAMs) on gold substrates: Gold-coated substrates or QCM gold crystals were incubated overnight in a $1.0 \mathrm{mM}$ mixed thiol solution of $\mathrm{HS}\left(\mathrm{CH}_{2}\right)_{11}\left(\mathrm{OCH}_{2} \mathrm{CH}_{2}\right)_{3} \mathrm{OH}$ and $\mathrm{HS}\left(\mathrm{CH}_{2}\right)_{11}\left(\mathrm{OCH}_{2} \mathrm{CH}_{2}\right)_{6} \mathrm{OCH}_{2} \mathrm{COOH}$ thiols (ProChimia TH 001-m11.n3-0,2 and TH 003-m11.n6-0,1) in absolute ethanol. Cell culture experiments were performed on $4 \%$ COOH SAMs, whereas other ratios were used for the QCM experiments (see results part). The substrates were rinsed with ethanol and Milli-Q water and then incubated in an aqueous solution of 0.2M EDC (N-(3-dimethylaminopropyl)-N'ethylcarbodiimide hydrochloride), 0.1M NHS (N-hydroxysuccinimide), 0.1M 2-(N-morpho)ethanesulfonic acid and $0.5 \mathrm{M} \mathrm{NaCl}$. After $15 \mathrm{~min}$ the solution was removed and the substrates were washed with deionized water and incubated in a $0.5 \mathrm{mg} / \mathrm{mL}$ solution of the RGD peptide (either cyclo[RGD(DMNPB)fK] or commercially available cyclo[RGDfK] or the negative control cyclo(RADfK) from Peptides International, USA) for $45 \mathrm{~min}$. The substrates were rinsed with PBS and dried with an $\mathrm{N}_{2}$ stream.

IR characterisation of the SAMs: IR spectra (4000-400 $\mathrm{cm}^{-1}$ with a resolution of $4 \mathrm{~cm}^{-1}$ and 1000 scans) were recorded with a Nicolet Magna-IR 850 Series II spectrometer. Measurements were performed on $50 \% \mathrm{COOH}$ terminated SAMs. 
Light irradiation of the substrates: Substrates for photolysis measurements and cell experiments were irradiated using a Xe-lamp coupled to a monochromator (Polychrome V, Till Photonics). Irradiation wavelength and irradiance were $350 \mathrm{~nm}$ and $0.6 \mathrm{~mW} \mathrm{~cm}$ respectively. For masked irradiation a quartz substrate containing a chrome micropattern $(100 \mu \mathrm{m}$ chrome stripes with $200 \mu \mathrm{m}$ spacing) was placed on the substrates during exposure. The substrates were rinsed with THF and Milli-Q water to remove photolysis products from the surface layer except for the cells experiments with in situ exposure. In this case the cell culture dish without lid was illuminated 5 minutes from the top, the light passed through the culture medium and the photolysis products remained in the medium. The photolysis conversion and quatum yield of surface bound chromophores were calculated following the methods and models specified in ${ }^{9}$.

QCM experiments: QCM measurements were carried out with a Q-Sense E1 Microbalance (Q-Sense, Göteborg, Sweden) using a window cell (QWM 401 from Q-Sense) which allowed in situ irradiation with a $365 \mathrm{~nm}$ LED source (NT65-940, Edmund Optics, Irradiance 4.5 $\mathrm{mWcm}^{-2}$ at the sample position). Experiments were performed on gold-coated quartz crystals (QS-QSX-301, Q-Sense), functionalized with RGD peptides as specified before at a controlled temperature of $25^{\circ} \mathrm{C}\left( \pm 0.05{ }^{\circ} \mathrm{C}\right)$. The solutions were injected at $50 \mu \mathrm{L} / \mathrm{min}$ flow rate. To switch between solutions, the flow was interrupted for a few seconds. The changes in the dissipation and normalized frequency, $\Delta f=\Delta f_{n} / \mathrm{n}$, presented in this work, correspond to values obtained for the third overtone $(n=3)$.

Integrin $\alpha_{\mathrm{V}} \beta_{3}$ (YO Proteins AB, Sweden) solutions were prepared in $50 \mathrm{mM}$ Tris- $\mathrm{HCl}(\mathrm{pH}=$ 7.4), $150 \mathrm{mM} \mathrm{NaCl}, 2 \mathrm{mM} \mathrm{MgCl}_{2} \cdot 6 \mathrm{H}_{2} \mathrm{O}, 1 \mathrm{mM} \mathrm{MnCl}_{2} \cdot 2 \mathrm{H}_{2} \mathrm{O}$. An integrin concentration of $\sim 20 \mu \mathrm{g} \mathrm{mL}{ }^{-1}$ was used unless otherwise stated.

A typical QCM experiment for integrin binding comprised the following steps. First the baseline was stabilized by flowing buffer solution into the QCM chamber, followed by injection of integrin solution at a flow rate of $50 \mu \mathrm{L} \mathrm{min}^{-1}$ during 4 minutes 30 seconds. The flow was stopped and the integrin was left to react with the surface for $35 \mathrm{~min}$ A rinsing step with buffer removed non-adsorbed protein from the QCM chamber. The integrin concentration of $\sim 20 \mu \mathrm{g} \mathrm{mL}^{-1}$ was selected as best compromise between the adsorbed and the consumed protein amounts after performing experiments at 2, 20 and $200 \mu \mathrm{g} \mathrm{mL}^{-1}$ (see Figure D supporting information). 
Cell culture: Human umbilical vein endothelial cells (HUVECs) were isolated and cultured in M199 basal medium (Sigma, M4530) supplemented with 2mM L-glutamine, 1000UmL ${ }^{-1}$ penicillin, and 100 $\mathrm{mgL}^{-1}$ streptomycin (Sigma), ECGS supplement (Sigma, E-2759), sodium heparin (Sigma, H-3393) and $20 \%$ of fetal calf serum (FCS) as previously described. ${ }^{10}$ The Cal 72 osteoblast cell line was obtained from ATCC and cultured as described. ${ }^{11}$ Mouse fibroblasts (NIH3T3) were cultured in DMEM medium (Invitrogen, Germany) supplemented with $10 \%$ fetal bovine serum (FBS), $1 \%$ L-glutamine (Invitrogen) at $37^{\circ} \mathrm{C}$ and $10 \% \mathrm{CO} 2$. Human foreskin fibroblasts were isolated from human foreskin tissue and cultured as previously described. ${ }^{12}$ Cells were incubated at $37^{\circ} \mathrm{C}$ in a $5 \%$ carbon dioxide environment. Before plating on the quartz substrates, cells were trypsinized with $0.25 \%$ trypsin and $1 \mathrm{mM}$ EDTA in Hanks' buffered salt solution. All experiments were conducted at $10^{5}$ cells $/ \mathrm{mL}$ and HUVEC and human foreskin fibroblasts at passages 2 to 4 . RGD-modified substrates were sterilized with ethanol $70 \%$ and then rinsed with PBS before cell seeding.

Cell patterns: Masked irradiated substrates containing $200 \mu \mathrm{m}$ light-exposed stripes separated by $100 \mu \mathrm{m}$ were sterilized with ethanol $70 \%$ and rinsed with PBS buffer. Human umbilical vein endothelial cells (HUVECs, grown as described) were seeded on the substrates and incubated at $37^{\circ} \mathrm{C}$ in a $5 \%$ carbon dioxide environment. After $4 \mathrm{~h}$ the medium (containing nonattached cells) was exchanged. Digital microscopic images were obtained with a phase contrast or fluorescence microscopy.

Cell gradients: Quartz substrates were irradiated using a custom-built setup which allows automated writing of micrometric patterns with adjustable light intensity and selectable wavelength. ${ }^{13}$ The setup is based on an inverted microscope (Leica DM-IRM) fixed onto an optical table. A laser at $404 \mathrm{~nm}$ (Z-laser Optoelektronik $\mathrm{GmbH})$ is routed through a beam expander and a dual axis galvanometer-based optical scanner (Edmund Optics GmbH) into the microscope through the side port. The scanner and other parts of the setup are controlled with custom developed software (Delphi) through an AD/DA-IO card (BMC Messsysteme $\mathrm{GmbH}$ ) and monitored with a digital camera (Oscar, Allied Vision Technologies GmbH), thus allowing automated irradiation of any chosen pattern in the field of view during any selected time at micrometer resolution. The patterns were written as three rectangle fields of $150 \mu \mathrm{m}$ width and $900 \mu \mathrm{m}$ length using different exposure doses corresponding to 25,100 and $50 \%$ of the maximum irradiation dose. 


\section{Results and discussion}

Cyclo[RGD(DMNPB)fK] was synthesized using an improved version of the previously reported protocol. ${ }^{3 \mathrm{~b}}$ The details for the synthesis of the DMNPB caged aspartic acid and the conditions for solid phase synthesis of the peptide as well as for the purification are provided as supporting information to this manuscript.

\section{Photolytic properties of cyclo[RGD(DMNPB)fK] in solution and surface bound}

The photolytic reaction of cyclo[RGD(DMNPB)fK] upon light exposure to yield uncaged cyclo[RGDfK] is represented in Figure 1. The photocleavage involves a light-induced abstraction of a benzylic $\mathrm{H}$ atom by the excited nitro group and a $\beta$-elimination to form the $o$ nitrostyrene derivative. ${ }^{14}$ The progress of the reaction was followed by the change in the UV spectrum of a solution of cyclo[RGD(DMNPB)fK] upon light exposure. Irradiation for times up to $31 \mathrm{~min}$ caused a decrease in the absorption maximum around $360 \mathrm{~nm}$, an increase in the absorption maximum around $300 \mathrm{~nm}$, and the appearance of a shoulder at $\lambda>400 \mathrm{~nm}$. These changes were also observed during irradiation of DMNPB-caged glutamate ${ }^{14 a}$ and are associated to the absorbance of the photolytic byproducts. Longer exposure doses caused a further change in the profile of the UV spectrum: the absorption maximum around $360 \mathrm{~nm}$ decreased again, while the shoulder at $\lambda>400 \mathrm{~nm}$ remained almost unchanged. The change in the spectrum is associated with photochemical side reactions of the byproducts. Quantitative HPLC analysis of a 26 min irradiated solution (figure $\mathrm{C}$ supporting information) revealed the presence of $36 \%$ free cyclo[RGDfK]. HPLC analysis of a solution after 90 minutes irradiation revealed $92 \%$ free cyclo[RGDfK], confirming high chemical yield of the photolytic reaction.

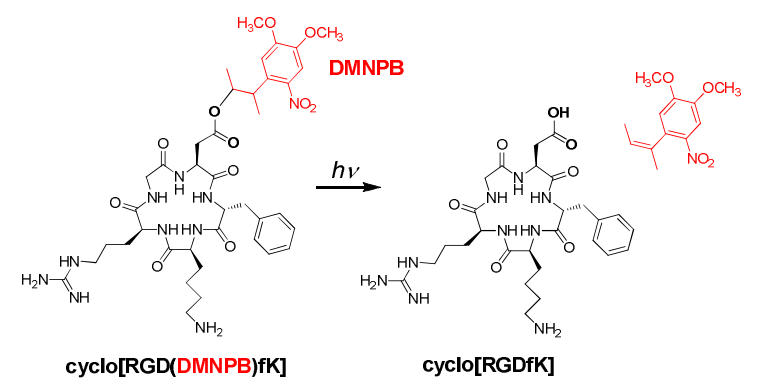



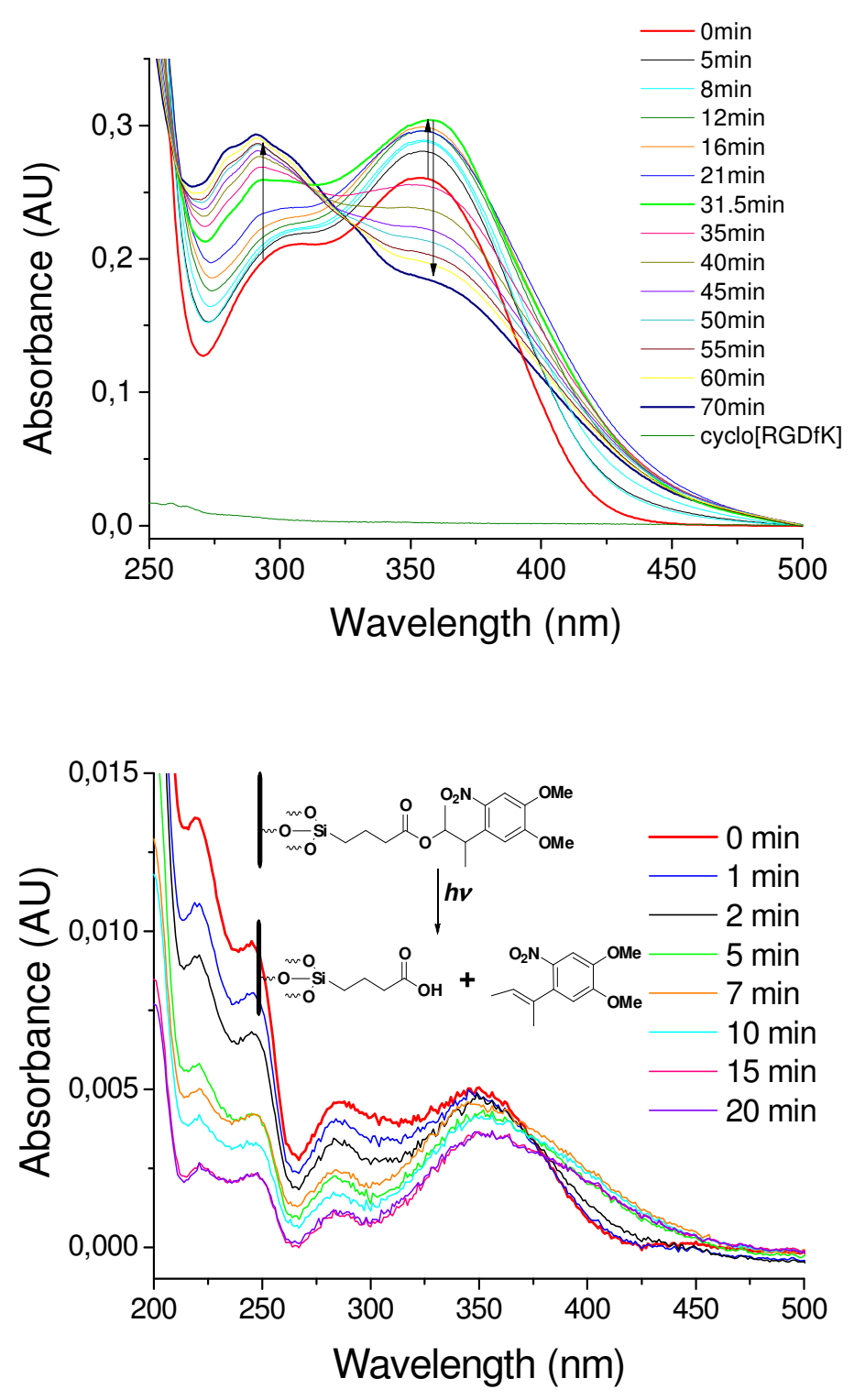

Figure 1: A) Photolytic reaction of cyclo[RGD(DMNPB)fK] including the photolysis byproduct; B) UV spectra of a $0.05 \mathrm{mM}$ solution of cyclo[RGD(DMNPB)fK] in PBS (pH 7.4) upon irradiation at $360 \mathrm{~nm}$ for increasing times. The UV spectrum of cyclo[RGDfK] at the same concentration is also shown for comparison. C) UV spectra of a quartz substrate modified with DMNPB-derivatized silane upon irradiation at $\lambda=365 \mathrm{~nm}$ in PBS buffer ( $\mathrm{pH}$ 7.4) for increasing times and after washing to remove the cleaved chromophore.

In order to follow the photolysis of DMNPB cage at the surface, we used DMNPB-protected, $\mathrm{COOH}$ terminated organosilane as model compound (see scheme in figure $1 \mathrm{C}$ ) for direct surface anchoring (see supporting information for details). This allowed us to obtain surface densities of chromophore high enough for direct detection of the chromophore by UV spectroscopy on quartz substrates (figure 1C). Layers with a surface density of the 
chromophore around $3.7 \times 10^{14}$ molecs $\mathrm{cm}^{-2}$ were prepared and irradiated. Upon exposure and washing, the UV spectrum showed a significant decrease in the UV absorbance, indicating removal of the chromophore from the surface. However, a residual absorbance at wavelengths $>300 \mathrm{~nm}$ was detected at full exposure (i.e. when the spectrum did not further change for longer exposure times), indicating the presence of surface bound chromophores after full uncaging, most likely due to photoactivated side-reactions of the styrene derivative at the surface. These results suggest that the exposed surface does not only contain the uncaged group (COOH in this case, or cyclo(RGDFK) in the next experiments), but also unspecifically reattached (or adsorbed) chromophores. This could be a limitation of our strategy in the biological application. However, the QCM and the cell results below will demonstrate that this was not the case for integrin binding to the uncaged surfaces.

\section{Immobilization of cyclo[RGD(DMNPB)fK] onto COOH terminated SAMs}

Carboxy-terminated, self-assembled monolayers (SAMs) of pegylated thiols on gold substrates were used as well-known biocompatible model surface layers for the experiments with integrins and cells. ${ }^{15}$ These are known to be protein and cell-repellent surfaces and, therefore, they could allow us to visualize and to quantify RGD-specific coupling or integrins or cells to the surface. Bicomponent SAMs containing different concentrations of $\mathrm{COOH}-(50$ to $1 \%$ ) and $\mathrm{OH}$-terminated thiols were prepared for the different applications and caged and non-caged cyclo[RGDfK] were covalently attached via the amine group of the Lys side chain using NHS/EDC standard coupling conditions. The coupling of the RGD to the SAM was confirmed by IR spectroscopy, as shown in Figure 2 for $50 \%$ COOH terminated SAMs. The Amide I $\left(\sim 1680 \mathrm{~cm}^{-1}, \mathrm{C}=\mathrm{O}\right.$ stretching vibration $)$ and amide II $\left(\sim 1530 \mathrm{~cm}^{-1}, \mathrm{~N}-\mathrm{H}\right.$ bending vibration and $\mathrm{C}-\mathrm{N}$ stretching vibration) bands of the peptide were clearly visible and confirmed the presence of the RGD peptide at the surface.

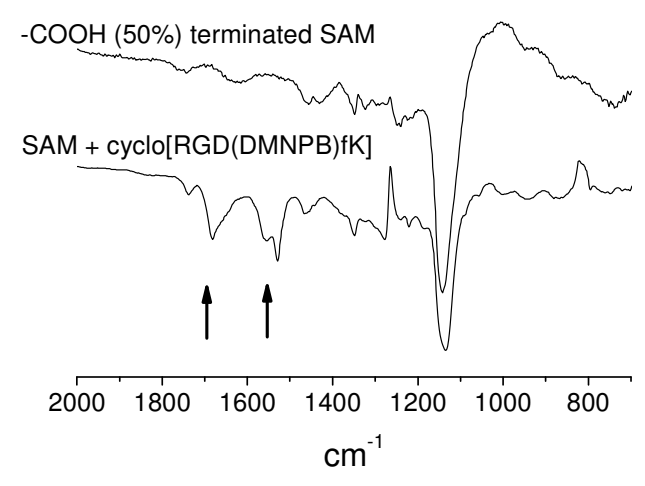


Figure 2: IR spectra of 50\% COOH-terminated SAM after coupling cyclo[RGD(DMNPB)fK] peptide. The IR spectrum of cyclo[RGD(DMNPB)fK] powder can be found as supporting information (Figure B).

\section{Integrin affinity to cyclo[RGD(DMNPB)fK] studied by $Q C M-D$}

The adsorption of integrin $\alpha_{V} \beta_{3}$ to substrates modified with cyclo[RGD(DMNPB)fK] prior and after irradiation was tested with QCM-D measurements. We first identified the best surface composition for maximizing RGD-mediated integrin binding and minimizing nonspecific interactions of the protein with the surface layer. ${ }^{16}$ For this purpose, QCM crystals were modified with SAMs containing 0.5 to $4 \%$ of the $\mathrm{COOH}$ terminated thiol, reacted with cyclo(RGDfK) and exposed to integrin solution. The coupling of the peptide involves a small mass change and could not be detected with the QCM when using SAMs with surface concentration of $\mathrm{COOH}$ groups $\leq 4 \%$. However, a clear change in the resonance frequency was observed in the QCM curves upon integrin injection. Figure 3 shows the frequency shifts obtained for the different compositions. Maximum binding was observed for the cyclo(RGDfK) surface layers containing $1 \% \mathrm{COOH}$. As negative control for testing nonspecific binding cyclo(RADfK) was used. QCM crystals modified with 4\% COOH-terminated layers modified with RAD showed a very weak frequency change upon integrin loading. These results indicate that integrin binding onto cyclo(RGDfK)-modified surfaces is specific and only mediated by the RGD peptide. As an additional control, binding experiments were performed without adding $\mathrm{Mn}^{2+}$ and $\mathrm{Mg}^{2+}$ in the buffer solution, since these cations are known to participate in the RGD-integrin binding site. A frequency shift $<5 \mathrm{~Hz}$ (see Figure $\mathrm{E}$ in Supporting Information) confirmed that integrin immobilization occurs via recognition of the RGD ligand at the surface.

Similar experiments were performed with cyclo[RGD(DMNPB)fK]. Integrin binding onto cyclo[RGD(DMNPB)fK]-modified QCM crystals was much lower than onto the active RGD (Figure 3). This result proofs that the DMNPB cage effectively inhibits the activity of the RGD peptide. The biggest affinity difference between caged and non-caged RGD (1:6) was observed onto RGD modified surfaces on $1 \% \mathrm{COOH}$-containing layers. This surface composition was used for further studies. 


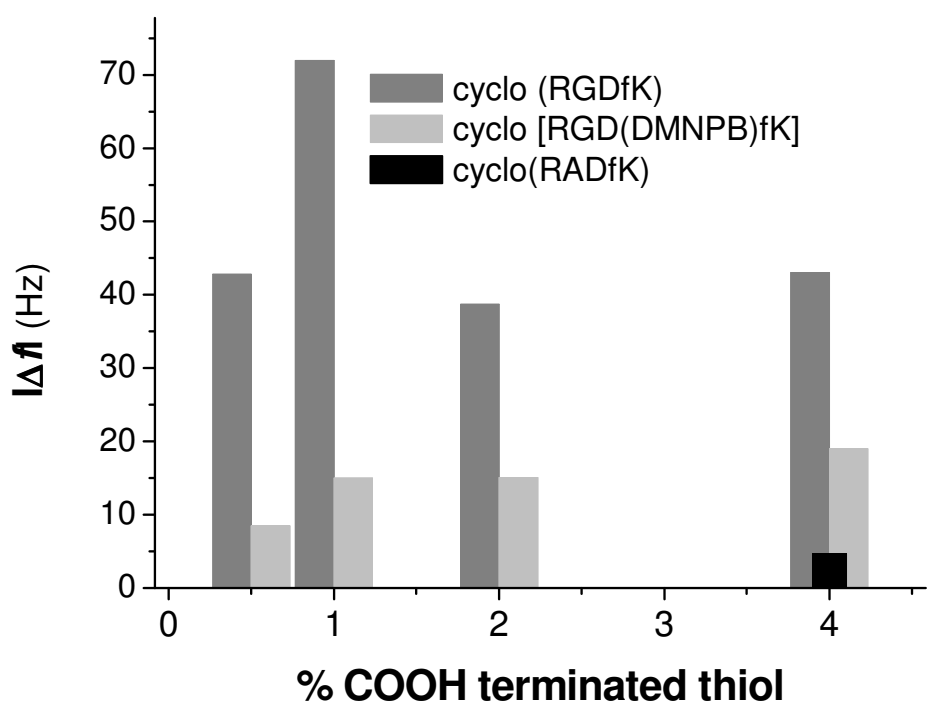

Figure 3. Frequency shift observed in QCM experiments upon integrin injection and posterior buffer rinsing step on substrates modified with different ratios of cyclo(RGDfK), cyclo[RGD(DMNPB)fK] and cyclo(RADfK).

The integrin binding onto cyclo[RGD(DMNPB)fK]-modified crystals after photocleavage of the DMNPB cage was tested with the QCM using a transparent window-cell for insitu lightexposure. The incubation step with integrin was performed under stop flow in order to minimize integrin consumption. Figure 4 shows the corresponding frequency and dissipation curves. Initially, the cyclo[RGD(DMNPB)fK]-modified crystal was incubated with the integrin solution under stopped flow for 35 minutes. A frequency shift of $10 \mathrm{~Hz}$ was observed after this incubation time. An additional small shift was detected when the flow was activated again, presumably due to the higher integrin concentration of the residual integrin solution that remained in the microfluidic tube before the washing step with buffer started. The attached integrin could not be removed by washing with buffer or with soluble RGD, suggesting that it could be immobilized via non-specific interactions. For the insitu uncaging reaction, a LED source was placed above the window-cell and the crystal was illuminated under conditions for full cleavage. The irradiation step induced a frequency change of $3 \mathrm{~Hz}$ of the crystal, but the original resonance frequency value was recovered when the LED was turned off. This frequency change has been observed in other cases and has been attributed to photoinduced noise. ${ }^{17}$ After washing with the buffer, the crystal was incubated with integrin for further 35 minutes and a frequency shift of $66 \mathrm{~Hz}$ was detected. This result indicates that surface-bound uncaged cyclo(RGDfK) has a higher affinity (almost 6-fold under our conditions) than cyclo[RGD(DMNPB)fK] for integrin binding, confirming that the light- 
triggered uncaging step activates the biological function of cyclo[RGD(DMNPB)fK]. Integrin binding onto crystals modified with cyclo(RGDfK) showed a similar frequency shift $(70 \mathrm{~Hz})$ after incubation for 35 minutes. These results demonstrate that the uncaging reaction at the surface worked with high yield and that the presence of photolytic byproducts at the surface does not significantly affect the bioactivity of the uncaged peptide in the application. Integrin binding to the crystal is also associated with a significant increase in the dissipation curves, as expected from the "soft" nature of a surface-attached protein layer.

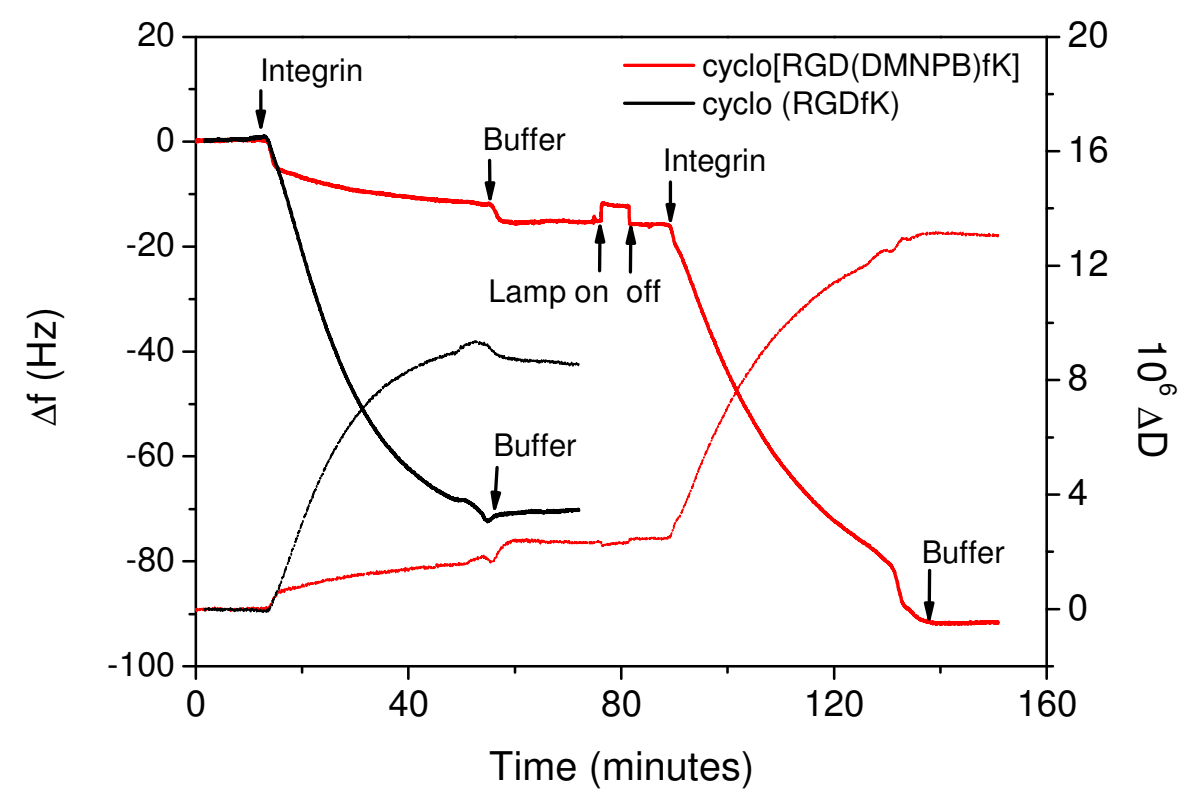

Figure 1 QCM-D shift of frequency (bold lines) and dissipation for experiments on crystals modified with cyclo[RGD(DMNPB)fK]. Crystals were first loaded with integrin, followed by a washing step, an irradiation step and a second loading of integrin. For comparison integrin loading on cyclo(RGDfK) modified crystals is also shown. Note that the incubation step with integrin was performed with stopped flow. The small frequency shift observed before the buffer washing step is associated to the small volume of integrin solution stored in the tube entering the incubation chamber and having higher integrin concentration.

\section{Spatial control of cell attachment: cell micropatterns}

Cyclo[RGDfK] and cyclo[RGD(DMNPB)fK]-terminated SAMs were seeded with HUVECs. The RGD sequence in fibronectin was originally shown to be the binding site for endothelial cells and this sequence has been demonstrated in fibrinogen, vWF, vitronectin, laminin, thrombospondin and type VI collagen. ${ }^{18}$ Cells rapidly attached and spread onto cyclo[RGDfK] already 4 hours after plating, but very poor attachment was observed on the cyclo[RGD(DMNPB)fK] substrate even after 5 days of culture (cells remained rounded-up and did not spread out).This indicated that the DMNPB cage effectively inhibited the 
recognition of the integrins on the cell membrane of the HUVEC cells and prevented cell adhesion (Figure 5). However, after irradiation and washing of cyclo[RGD(DMNPB)fK]modified substrates, and then adding HUVEC cells, the cells were found to rapidly attach to the substrate, and showed a similar pheontype to the cyclo[RGDfK] control. This indicated that the DMNPB chromophore was cleaved and cyclo[RGDfK] groups became available and functional for cell attachment.
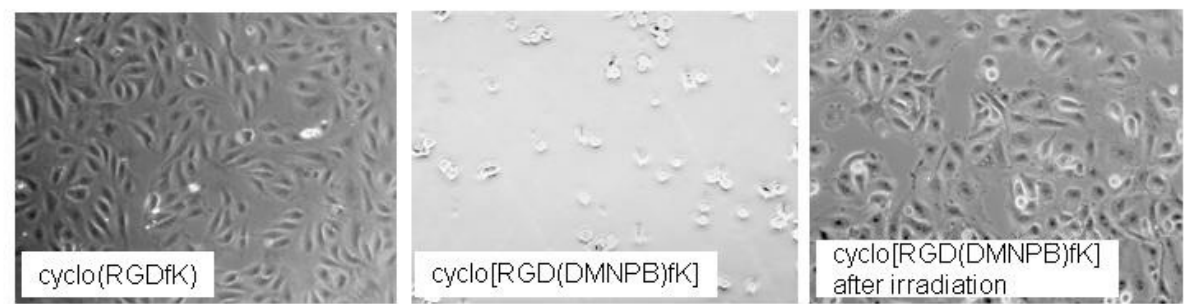

Figure 5: HUVECs onto RGD-modified substrates after 4 hours plating (and irradiation in c)

In order to test the possibility to spatially and specifically control cell attachment, cyclo[RGD(DMNPB)fK]-functionalized substrates were irradiated through a quartz mask containing $100 \mu \mathrm{m}$ chrome stripes separated by $200 \mu \mathrm{m}$ and afterwards cells were added. HUVECs attached to and spread out selectively on the irradiated regions and formed well defined cell patterns (Figure 6). The patterns were maintained over 10 days (see Figure F supporting information). HUVECs did not migrate to the regions where the RGD was caged and there were clear cutoffs reflecting the mask geometry used in the irradiation step. These results suggest a dramatic difference in the affinity of cyclic (RGDfK) and the caged derivative for integrin recognition, most probably much higher than the 6 fold difference detected by QCM experiments. It is important to note that integrins in solution used for the QCM experiments were not in their native environment (i.e. embedded in the cellular lipid bilayer) and, therefore, their conformation and functionality could be different than in the native state.

Similar experiments were performed with a mouse fibroblast cell line and primary human fibroblasts and a human osteoblast cell line. The fibroblasts (NIH3T3) showed less clear patterns compared to the HUVEC cells and attachment was not limited to the irradiated region. Human osteoblasts (CAL-72) and primary human fibroblasts attached to all regions of the substrate in similar amounts, whether irradiated or not (Fig. 6). This is not surprising, since it is well known that both of these cell types rapidly attach to normal cell culture plastic 
substrates and other substrates such as glass without the prior coating with matrix proteins. This is in contrast to HUVEC, which generally exhibit very poor attachment to cell culture plastic and no attachment to glass substrates without coating with matrix proteins. More cellrepellent substrate backgrounds than the SAMs (i.e. PEG hydrogels) would most likely be required in cases where exclusive RGD-mediated binding is required.
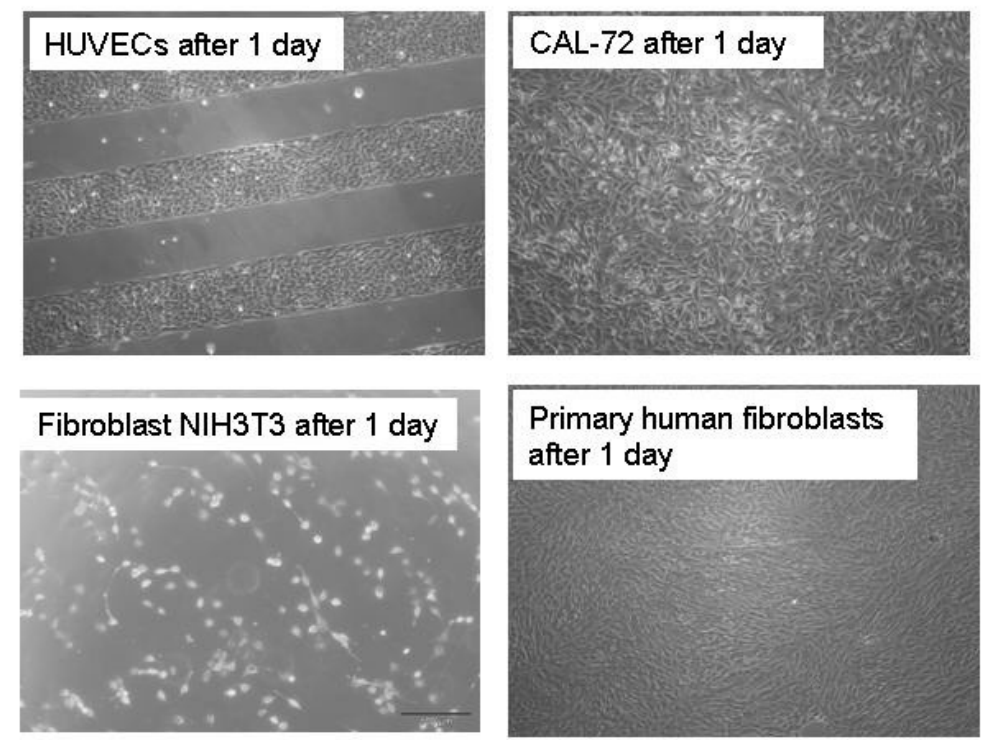

Figure 6: Images of different cell types seeded onto cyclo[RGD(DMNPB)fK] after masked irradiation to obtain cell patterns. The indicated cells were added and images were taken after 24 hrs.

Control of RGD surface concentration by the irradiation dose: generation of cell gradients Substrates modified with cyclo[RGD(DMNPB)fK] were exposed to a laser beam at different irradiation intensities. Linear patterns of $150 \mu \mathrm{m}$ were written using a laser and irradiation doses for which we expected a $25 \%, 50 \%$ or $100 \%$ photocleavage of the DMNPB chromophore. In this way, a micropattern with a gradient in the concentration of uncaged RGD was generated on the surface. HUVECs were seeded onto the patterned substrates in order to determine if a difference in adherence pattern was observed, depending on the percentage of photocleavage of the DMNPB. Figure7A shows an image of HUVECs 2 hours after addition of cells to this substrate. As can be seen, a differing number of cells attached and spread out on the different regions depending on the extent of the uncaging reaction. Very few HUVEC were observed on the $25 \%$, a few on the $50 \%$ and a larger number of cells on the $100 \%$ photocleavaged DMNPB surface. After $24 \mathrm{hrs}$, almost no cells remained on the $25 \%$ (data not shown), cells on the $50 \%$ have begun to increase and on the $100 \%$ photocleavaged 
surface, the entire surface was covered with cells. These images also demonstrate that between the photocleavaged areas, rounded-up HUVEC cells could be observed that were in the process of detaching. This indicates that the surface between the photocleavage treated areas does not support HUVEC growth. In summary, a direct correlation between photocleavage ratio and cell density was visible and the correlation was maintained during the 24 hour culture period.(Figure 7B). In this way, light-controlled, gradient patterns influencing cell attachment and density could be demonstrated.

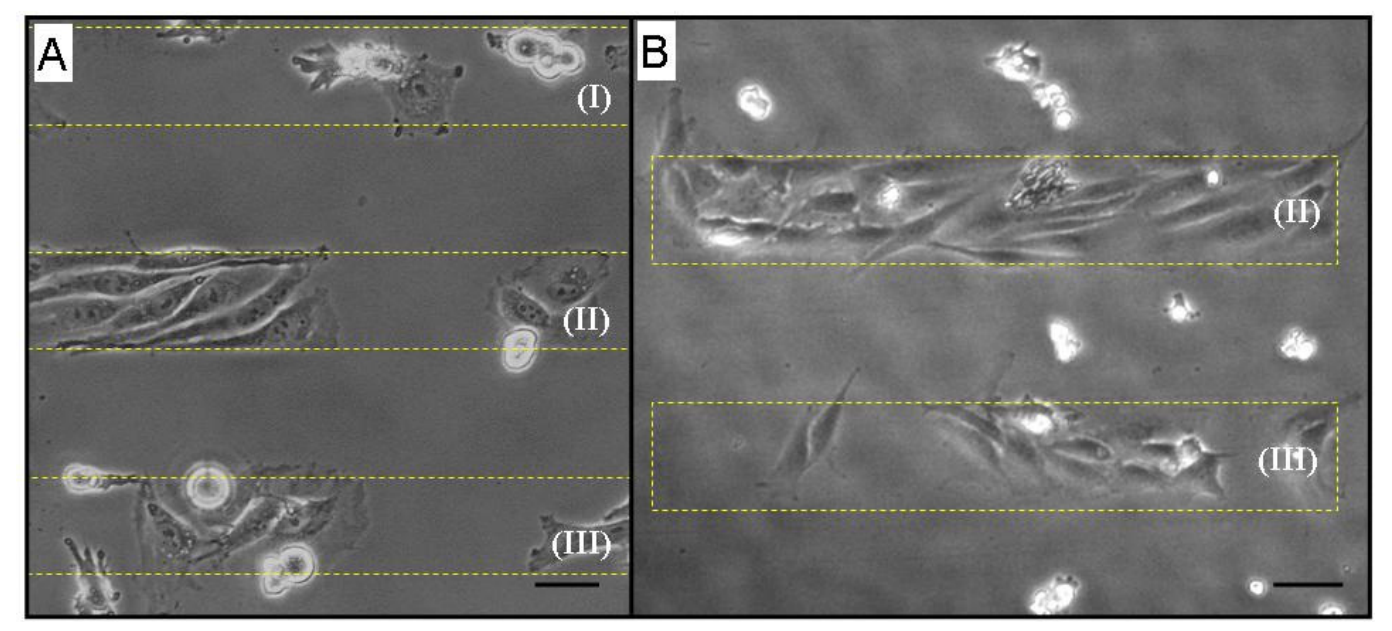

Figure 7: HUVECs onto cyclo[RGD(DMNPB)fK]-modified surfaces that were scanned with a laser with different intensities. A) Three stripes of $150 \mu \mathrm{m}$ width (marked with discontinous lines) were irradiated using exposure doses to achieve $25 \%$ (I), 100\% (II) and 50\% (III) uncaging of the DMNPB groups at the surface. The image shows HUVECs 2 hours after incubation on those substrates. The differences in cell density reflect the differences in the surface concentration of RGD after controlled exposure. B) Microscope image of the HUVECs on regions (II) and (III) after $24 \mathrm{hrs}$ incubation. It shows that the differences in cell density onto the patterns were maintained over time. Scale bar $100 \mu \mathrm{m}$.

\section{Conclusions}

Photoactivatable, caged cyclo[RGD(DMNPB)fK] allows phototriggering of integrin-binding events that influence cell attachment to surfaces. The caged peptide showed low affinity for integrins. Light exposure removed the DMNPB cage and restored the ability of cells to bind integrin and, consequently, mediated cell adhesion. Although only a 6-fold affinity difference was measured for soluble integrin between the caged and uncaged peptides, HUVECs showed an impressive selective attachment to the uncaged RGD after light treatment, similar to the control. Other cell types did not exhibit this characteristic. In addition, the amount of cells 
that attach could be controlled, depending on the amount of the photocleaving exposure of the substrate. Thus, a particular cell type could be directed to a specific area of a substrate and the amount of cells that attached could be controlled. Our results demonstrate that surfaceimmobilized, caged peptides represent promising tools for new studies in cell biology that allow direct and spatiotemporally defined control over molecular interactions with cell membrane receptors. These results also indicate that human cells differ in their response to the RGD moiety and this information may be valuable in tissue engineering, biomaterial or drugtargeting strategies.

\section{Acknowledgements}

The authors thank Martina Knecht for help in the synthetic part and Alexander Specht and Maurice Goeldner (University Strasbourg) for previous work in the caged RGD and discussion of the photolysis experiments. AdC and VSM thank the DFG for financial support (DFG-ANR project, CA880-3). AdC and MW thank the Materials World Network (DFG AOBJ 569628) for financial support. 


\section{SUPPORTING INFORMATION}

\section{Photoactivatable caged cyclic RGD peptide for triggering integrin binding and cell adhesion to surfaces}

Melanie Wirkner ${ }^{(1)}$, Simone Weis ${ }^{(1)}$, Dr. Verónica San Miguel, ${ }^{(1)}$ Dr. Marta Álvarez ${ }^{(1)}$, Dr. Radu A. Gropeanu ${ }^{(1)}$, Dr. Marcelo Salierno ${ }^{(1)}$, Anne Sartoris ${ }^{(2)}$, Dr. Ronald E. Unger ${ }^{(2)}$, Prof. C. James Kirkpatrick ${ }^{(2)}$, Dr. Aránzazu del Campo ${ }^{(1)} *$

${ }^{(1)}$ Max-Planck-Institut für Polymerforschung, Ackermannweg 10, 55128 Mainz, Germany

(2) Institute of Pathology, University Medical Center of the Johannes Gutenberg University Mainz, Langenbeckstrasse 1, 55101 Mainz, Germany

*contact : e-mail: delcampo@mpip-mainz.mpg.de

Tel: +496131379563

Fax +496131379271

1. Synthesis of DMNPB caged Aspartic acid

2. Synthesis of cyclo[RGD(DMNPB)fK] via SPPS

Figure A: ${ }^{1} \mathrm{H}-\mathrm{NMR}$ spectrum of cyclo[RGD(DMNPB)fK]

Figure B: IR spectrum of cyclo[RGD(DMNPB)fK]

Figure C: HPLC analysis of irradiated solution of cyclo[RGD(DMNPB)fK]

3. Synthesis of DMNPB caged $\mathrm{COOH}$-terminated silane and preparation and characterisation of surface layers

4. QCM experiments

Figure D: QCM data for different integrin concentrations

Figure E: QCM data in the absence of $\mathrm{Mn}^{2+}$ and $\mathrm{Mg}^{2+}$

5. Cell images

Figure F: 


\section{Synthesis of DMNPB caged Aspartic acid}

The synthesis of DMNPB caged- and Fmoc-protected aspartic acid (f) was done following the scheme below by adapting a method described elsewhere. ${ }^{14 a}$

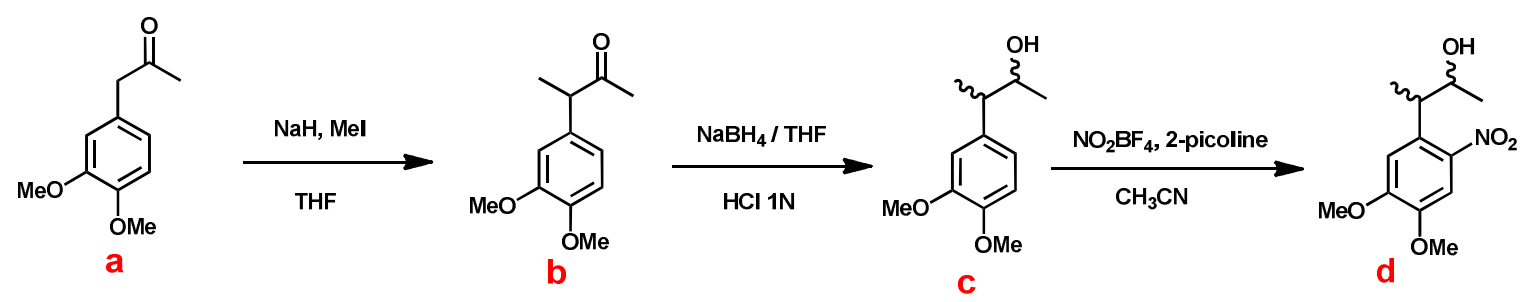

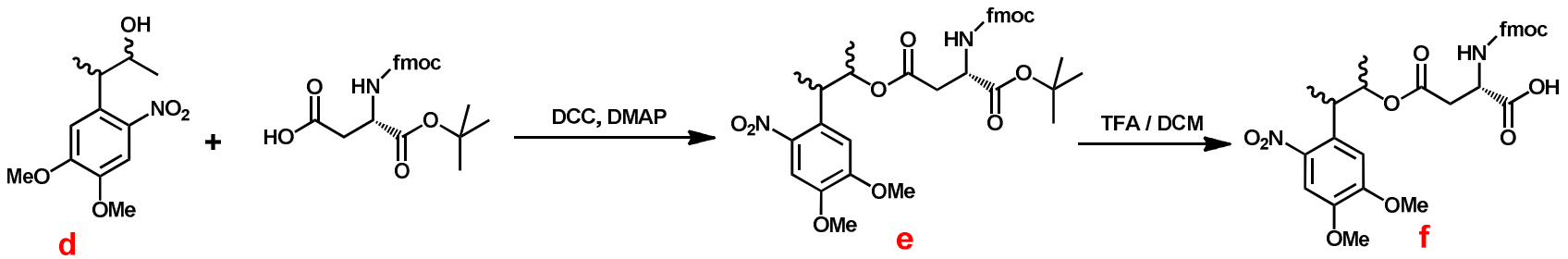

Materials and methods: 3,4-dimethoxy-acetophenone (a), sodium borohydride, 4-(N,Ndimethyl)amino-pyridine (DMAP), dry THF, dry acetonitril, methyl iodide, nitronium tetrafluoroborate, N,N'-dicyclohexyl-carbodiimide (DCC), trifluoroacetic acid (TFA) (Acros, Geel, Belgium), sodium hydride (ABCR GmbH, Karlsruhe, Germany), $\alpha$-tert-butyl N-FmocL-aspartate (Bachem, Bubendorf, Switzerland) were bought and used without any other purification.

${ }^{1} \mathrm{H}-\mathrm{NMR}$ spectra were measured at room temperature with Brucker Avance $250(250 \mathrm{MHz})$ and Brucker Avance 700 (700 MHz) spectrometers. ESI-MS spectra were recorded using a QTos Ultima 3. HPLC analysis and purification of the compounds was performed with a JASCO HPLC 2000 equipped with a diode array UV-Vis detector and fraction collector. Reprosil C18 columns were used for semi-preparative $(250 \times 25 \mathrm{~mm})$ and analytical $(250 \times 5$ $\mathrm{mm})$ runs.

3-(3,4-dimethoxyphenyl)-butan-2-one, (b): $1.94 \mathrm{~g}$ of a (10 mmol, 1 equiv.) were poured dropwise at r.t. to a suspension of sodium hydride $(0.4 \mathrm{~g} \mathrm{NaH} 60 \%$ in paraffin suspesion, 10 mmol, 1 equiv.) in $25 \mathrm{ml}$ dry THF. After 30 minutes stirring at r.t., the suspension was cooled to $0^{\circ} \mathrm{C}$ and $0.75 \mathrm{ml}$ methyl iodide $\left(11.9 \mathrm{mmol}, 1.19\right.$ equiv.) were added. After stirring at $0^{\circ} \mathrm{C}$ for 30 minutes, the cooling bath was removed and the reaction mixture was stirred 1 hour at 
r.t. Then, $100 \mathrm{ml}$ of saturated solution of $\mathrm{NaHCO} 3$ were added, the aqueous layer was extracted twice with $100 \mathrm{ml}$ ethyl acetate, the combined organic layers were washed with brine and dried over $\mathrm{MgSO}$, and the solvent was removed in vacuum to afford the crude product as pale yellow oil (1.98 g, yield 96\%).

3-(3,4-dimethoxyphenyl)-butan-2-ol, (c): $500 \mathrm{mg}$ sodium borohydride (13.1 mmol, 1.4 equiv.) were added at r.t. to a solution of $1.9 \mathrm{~g}$ of $\mathbf{b}$ ( $9.1 \mathrm{mmol}, 1$ equiv.) in $10 \mathrm{ml}$ THF and 20 $\mathrm{ml}$ 2-propanol, and the resulted suspension was stirred at r.t. for $1 \mathrm{hr}$. The unreacted sodium borohydride was quenched with $1 \mathrm{M}$ aqueous $\mathrm{HCl}$. To the reaction mixture $200 \mathrm{ml}$ water and $100 \mathrm{ml}$ ethyl acetate were added and the aqueous layer was extracted with $100 \mathrm{ml}$ ethyl acetate. The combined organic layers were washed with water and brine, and were dried over MgSO4. The solvent was removed in vacuum to afford the crude product as pale yellow oil. The crude product was purified via column chromatography (silicagel, 3:1 hexane/acetone) to afford the product as a erythro-threo mixture (1.9 g, 99\% yield).

3-(4,5-dimethoxy-2-nitro-phenyl)-butan-2-ol, (d): $0.9 \mathrm{~g}$ nitronium tetrafluoroborate (6.8 mmol, 1.4 equiv.) were dissolved at $-30^{\circ} \mathrm{C}$ in $15 \mathrm{ml}$ of dry acetonitril and $0.7 \mathrm{ml}$ 2-picoline (7.2 mmol) were added dropwise. After 30 minutes, a solution of $1 \mathrm{~g}$ of $\mathbf{c}$ (4.7 mmol, 1 equiv.) in $10 \mathrm{ml}$ dry acetonitril was slowly added and the reaction mixture was stirred 1 hour at $-30^{\circ} \mathrm{C}$ and overnight at r.t. The unreacted nitronium complex was quenched with $100 \mathrm{ml}$ of saturated solution of sodium bicarbonate and the aqueous layer was extracted twice with $100 \mathrm{ml}$ ethyl acetate. The combined organic layers were washed with $100 \mathrm{ml}$ water, brine and the solvent was removed in vacuum. The brown residue was purified via column chromatography (silicagel, 2:1 hexane/acetone) to give $0.74 \mathrm{~g}$ (61\% yield) of the $d$ as erythro-threo isomers mixture.

$\alpha$-tert-butyl $\delta$-[3-(4,5-dimethoxy-2-nitro-phenyl)-2-butyl]-N-Fmoc-L-aspartate, (e): To a solution of $255 \mathrm{mg} \mathrm{d}$ ( $1 \mathrm{mmol}, 1$ equiv.) in $10 \mathrm{ml}$ dry dichloromethane were added, in the following order, $\alpha$-tert-butyl N-Fmoc-L-aspartate (411 mg, $1 \mathrm{mmol}, 1$ equiv.), DCC (200 mg, $1 \mathrm{mmol}, 1$ equiv.) and DMAP (10 mg, $81 \mu \mathrm{mol}, 0.08$ equiv.). After the reaction mixture was stirred overnight under Ar at r.t., $100 \mathrm{ml}$ saturated sodium bicarbonate solution were added, the aqueous layer was extracted twice with $100 \mathrm{ml}$ ethyl acetate, combined organic layers were washed with $100 \mathrm{ml}$ water, dried with brine and over $\mathrm{MgSO}_{4}$, and the solvent was 
removed in vacuum. The brown residue was purified via column chromatography (silicagel, 4:1 hexane/acetone) to give $455 \mathrm{mg}$ (70\% yield) of the $\mathrm{d}$ as erythro-threo isomers mixture.

Fehler! Es ist nicht möglich, durch die Bearbeitung von Feldfunktionen Objekte zu erstellen.

${ }^{1} \mathrm{H}-\mathrm{NMR}\left(\mathrm{CDCl}_{3}, 250 \mathrm{MHz}\right) \delta(\mathrm{ppm}): 1.23-1.26\left(3 \mathrm{H}, \mathrm{m},-\mathrm{CH}_{3} \mathrm{e}\right) ; 1.29-1.33\left(3 \mathrm{H}, \mathrm{m},-\mathrm{CH}_{3} \mathrm{~d}\right)$; 1.42-1.47 (9H, m, - $\left.\mathrm{CH}_{3} \mathrm{OtBu}\right) ; 2.60-2.98\left(2 \mathrm{H}, \mathrm{m}, \mathrm{CH}_{2}\right.$ b); 3.72-3.97 (7H, $\mathrm{OCH}_{3}$ meta, $\mathrm{OCH}_{3}$ para, CH f); 4.22-4.50 (4H, m, CH c, CH j, CH2 i); 5.14-5.30 (1H, m, CH a); 5.57-5.76 (1H, m, NH); 6.876-6.88 (1H, m, CH h); 7.3-7.42 (5H, m, CH g, CH 1, CH m); 7.54-7.59 (2H, m, $\mathrm{CH} \mathrm{k}) ; 7.76(2 \mathrm{H}, \mathrm{d}, 3 \mathrm{~J}=7.5 \mathrm{~Hz}, \mathrm{CH}$ n).

ESI-MS: $648(\mathrm{M}+)$.

$\boldsymbol{\alpha}$-tert-butyl $\boldsymbol{\delta}$-[3-(4,5-dimethoxy-2-nitro-phenyl)-2-butyl]-L-aspartate, (f): $200 \mathrm{mg}$ of e were dissolved in $2 \mathrm{ml}$ DCM:TFA (1:1) mixture and the solution was stirred under Ar at r.t. for 1 hour. After the solvent was removed using a nitrogen stream, $5 \mathrm{ml}$ of DCM were added, and the solution was dried again under the nitrogen stream. The yellow-brown residue was dissolved in acetonitril and purified by HPLC (water:ACN, gradient from 50\% ACN to 100\% ACN), resulting $170 \mathrm{mg}$ (93\% yield) of $\mathrm{f}$ as yellow solid.

Fehler! Es ist nicht möglich, durch die Bearbeitung von Feldfunktionen Objekte zu erstellen.

${ }^{1} \mathrm{H}-\mathrm{NMR}\left(\mathrm{CDCl}_{3}, 250 \mathrm{MHz}\right) \delta(\mathrm{ppm}): 1.23-1.26\left(3 \mathrm{H}, \mathrm{m},-\mathrm{CH}_{3} \mathrm{e}\right) ; 1.29-1.33\left(3 \mathrm{H}, \mathrm{m},-\mathrm{CH}_{3} \mathrm{~d}\right)$; 2.54-2.91 (2H, m, $\mathrm{CH}_{2}$ b); 3.72-3.97 (7H, $\mathrm{OCH}_{3}$ meta, $\mathrm{OCH}_{3}$ para, $\mathrm{CH}$ f); 4.22-4.50 $(4 \mathrm{H}, \mathrm{m}$, $\mathrm{CH}$ c, $\mathrm{CH}$ j, $\mathrm{CH} 2 \mathrm{i}) ; 4$.46-4.61 (1H, m, $\mathrm{CH}$ a); 5.51-5.70 (1H, m, NH); 6.86-6.88 (1H, m, CH h); 7.30-7.42 (5H, m, CH g, CH 1, CH m); 7.54-7.59 (2H, m, CH k); $7.76(2 \mathrm{H}, \mathrm{d}, 3 \mathrm{~J}=7.5 \mathrm{~Hz}$, $\mathrm{CH}$ ).

ESI-MS: $615.24(\mathrm{M}+\mathrm{Na})+$

\section{Synthesis of cyclo[RGD(DMNPB)fK] via SPPS}




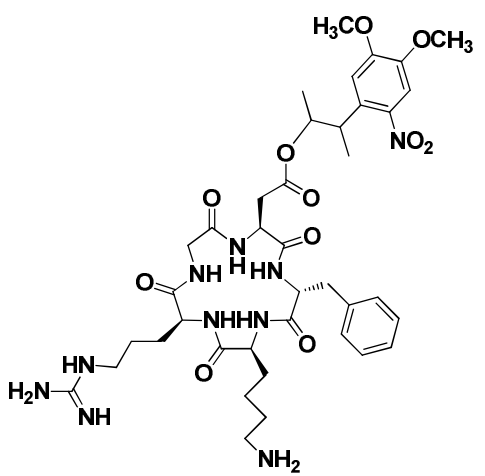

Materials and methods: Chemicals and solvents were purchased from Sigma-Aldrich Chemie GmbH (D-89555), Acros Organics (Geel, Belgium), Bachem Distribution Services GmbH (79576-Weil am Rhein) and Merck KGaA (D-64271). Solvents had p.a. purity and were used as obtained unless specified. Solid phase peptide synthesis (SSPS) was performed using syringes of $5 \mathrm{ml}$ and $10 \mathrm{ml}$ volume as reaction vessels equipped with PE-filters (CEL053 and CEL-1016), Roland Vetter Laborbedarf OHG, Ammerbuch) for washing steps. Trityl-linker resin (TCP-resin, 1,4-1,5 mmol Cl/g, 100-200 mesh) was obtained from PepChem Intavis AG Bioanalytical Instruments (D-72770 Reutlingen).

Coupling of Fmoc-Gly-OH: A syringe was weighed and filled with TCP-resin. A solution of 1.1 eq. of Fmoc-Gly-OH and 5.6 eq. of N,N-Diisopropylethylamine (DIPEA) in absolute DCM ( $8 \mathrm{ml} / \mathrm{g}$ of resin) was added, and the suspension was vigorously shaked in the syringe for 1.5 hours. $\mathrm{MeOH}(1 \mathrm{ml} / \mathrm{g}$ of resin) was added and the mixture was shaked for further 20 min. The solution was filtered out and the resin was washed with DCM, three times with DMF, three times with DCM and twice with $\mathrm{MeOH}$. The resin was left in a desiccator filled with silica gel under vacuum overnight for drying. The amino acid loading on the resin could be calculated as follows.

Fehler! Es ist nicht möglich, durch die Bearbeitung von Feldfunktionen Objekte zu erstellen.

$\mathrm{n} \quad$ loading density [mmol AA/g loaded resin]

$\mathrm{m}_{1} \quad$ weight of untreated resin $[\mathrm{g}]$

$\mathrm{m}_{2} \quad$ weight of loaded resin [g]

$\mathrm{M}_{\mathrm{AA}}$ molecular weight of Fmoc-AA [g/mol]

$\mathrm{M}_{\mathrm{HCl}} \quad 36,46 \mathrm{~g} / \mathrm{mol}$ 
Synthesis of linear H-Asp(DMNPB)-D-Phe-Lys(Boc)-Arg(Pbf)-Gly-OH: The preparation of the linear peptide follows the Fmoc-strategy (Table 1) and started from 0.19 mmol of Glyloaded resin. Deprotection of the Fmoc-group was performed by reacting the resin twice for 10 minutes with $20 \%$ piperidine in DMF under vigorous shaking. The resin was washed five times with DMF. To couple the next amino acid, a solution of the Fmoc-amino acid, HOBt, HBTU, and DIPEA in DMF (10-15 ml/g of resin) was added to the reaction vessel and left to react under vigorous shaking. The coupling conditions for each of the Fmoc-amino acids (Arg(Pbf), Lys(Boc), D-Phe and Asp(DMNPB)) are specified in Table 1. The coupling solution was then filtered out and the resin was washed five times with DMF.

Cleavage of the protected linear peptide from the resin was performed by treating the resin once with $1.5 \mathrm{ml}$ and twice with $3 \mathrm{ml}$ of a solution of trifluorethanol/acetic acid/DCM (1/3/6) for $30 \mathrm{~min}$ each. Toluene was added to the filtrate and the solvents were removed in vacuum. $119 \mathrm{mg}$ (0.1 mmoles) of crude product was obtained from 0.19 mmoles of TCP-resin.

Table 1. Solid Phase Peptide Synthesis using Fmoc-strategy

\begin{tabular}{|l|l|l|l|}
\hline Step & Reagent / solvent & Time & Cycle \\
\hline 1 & $20 \%$ Piperidine / DMF & 10 min & Deprotection \\
\hline 2 & $20 \%$ Piperidine / DMF & 10 min & Deprotection \\
\hline 3 & DMF & & $5 \times$ washing \\
\hline 4 & Coupling solution & $(*)$ min & Coupling \\
\hline 5 & DMF & & $5 \times$ washing \\
\hline
\end{tabular}

(*) Fmoc-Arg(Pbf)-OH (3h), Fmoc-Lys(Boc)-OH (3h), Fmoc-D-Phe-OH (3,5 h), Fmoc-Asp(DMNPB)-OH (4 h)

Table 2. Coupling conditions for the different aminoacids

\begin{tabular}{|l|l|l|l|l|}
\hline & $\operatorname{Arg}(\mathrm{Pbf})$ & Lys(Boc) & D-Phe & Asp(DMNPB) \\
\hline Fmoc-amino acid / eq. & 2 & 2 & 2.5 & 1.3 \\
\hline HOBT / eq. & 2 & 2 & 2.5 & 1.3 \\
\hline HBTU / eq. & 2 & 2 & 2.5 & 1.4 \\
\hline
\end{tabular}




\begin{tabular}{|l|l|l|l|l|}
\hline DIPEA / eq. & 6 & 6 & 7 & 5 \\
\hline DMF / ml & 1.7 & 1.7 & 2 & 2.3 \\
\hline
\end{tabular}

Synthesis of Cyclo[-Asp(DMNPB)-D-Phe-Lys(Boc)-Arg(Pbf)-Gly-]: The cyclization of the protected linear peptide was performed in solution using diphenylphosphoryl azide (DPPA) as coupling reagent. The protected peptide $(119 \mathrm{mg}, 0.1 \mathrm{mmoles})$ was dissolved in DMF (20 ml, $\mathrm{c}=5 \mathrm{mM}$ ). NaHCO3 (42.2 mg, 0.5 mmoles) and DPPA (64 $\mu 1,0.3$ mmoles) were added and the reaction mixture was stirred at room temperature for a period of 48 hours. After filtering off the NaHCO3, the solution was concentrated at $40^{\circ} \mathrm{C}$ using high vacuum. The cyclo peptide was precipitated in water and dried in high vacuum to give 0.1 mmoles of crude product. Yield $99 \%$.

Hydrolysis of protecting groups: Cyclo[-Asp(DMNPB)-D-Phe-Lys(Boc)-Arg(Pbf)-Gly-] ( 0.1 mmoles) was dissolved in $800 \mu 1$ of TFA/H2O $(760 \mu 1 / 40 \mu 1)$ and stirred for 1.5 hours. Solvent was evaporated to $20 \%$ of the initial volume and $15 \mathrm{ml}$ diisopropyl ether were added. The precipitate was centrifuged and dried in high vacuum to give $96 \mathrm{mg}$ ( 0.1 mmoles $)$ of crude product.

HPLC purification: The crude product was purified twice by RP-HPLC using water/acetonitrile containing $0.1 \%$ TFA as eluents. By increasing the volume fraction of acetonitrile after a 3 min run from $10 \%$ to $40 \%$ within 15 min and successively keeping this ratio for another $9 \mathrm{~min}$ the product signal appears between 18 and $19 \mathrm{~min}$. The pure fractions were collected and freeze dried to give a yellow powder. $35 \mathrm{mg}$ (0.04 mmoles) of solid were obtained from $96 \mathrm{mg}$ of crude product. Yield 36.5\%. MS ES+: 841.40. 


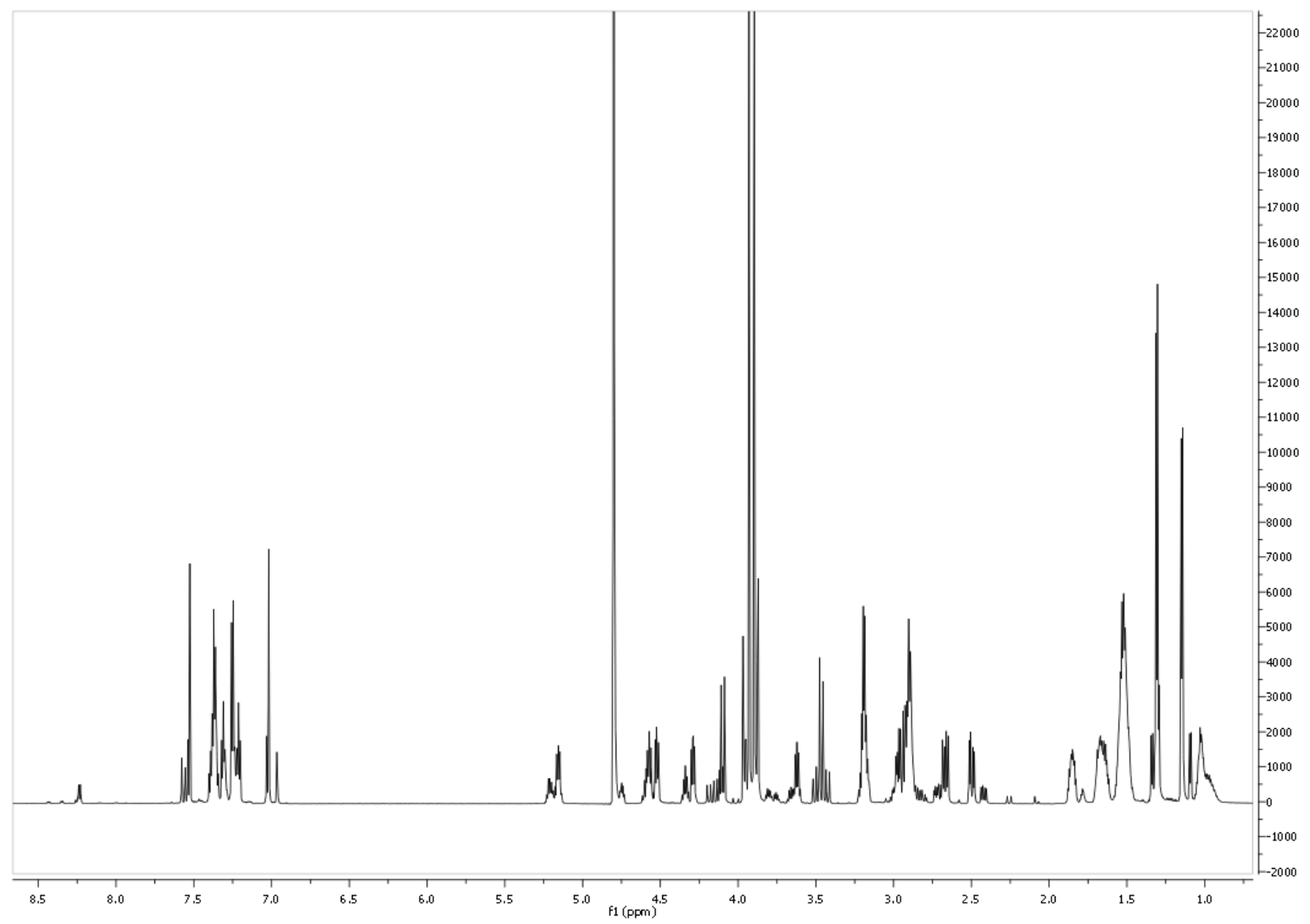

Figure A. ${ }^{1} \mathrm{H}-\mathrm{NMR}$ spectrum of cyclo[RGD(DMNPB)fK] in $\mathrm{D}_{2} \mathrm{O}(700 \mathrm{MHz})$

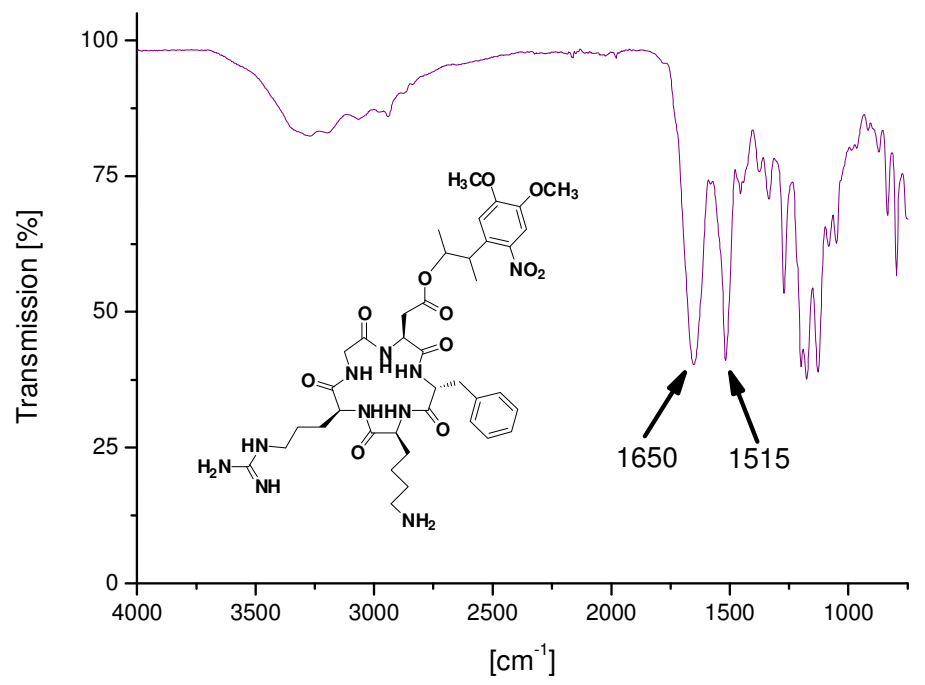

Figure B: IR spectrum of cyclo[RGD(DMNPB)fK] 


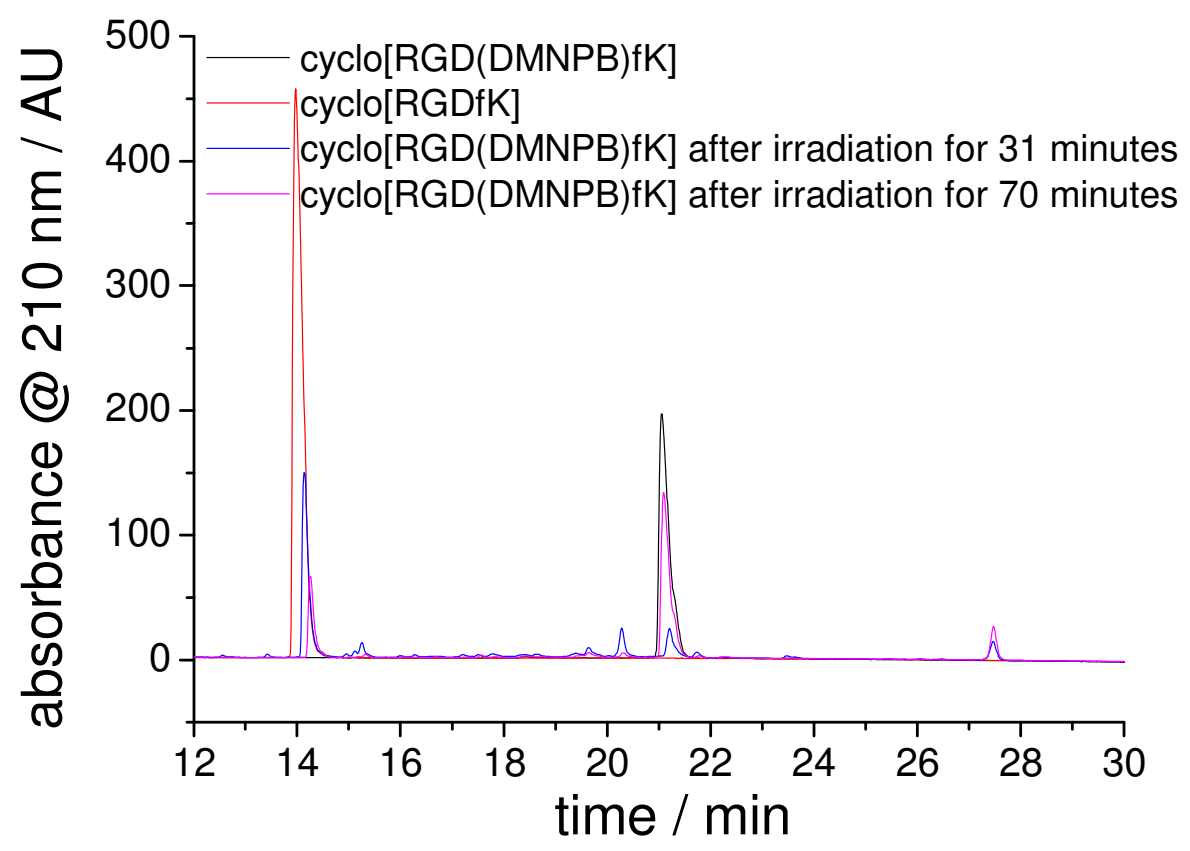

Figure C. Analytical HPLC chromatogram of the synthesized cyclo[RGD(DMNPB)fK], of commercially available cyclo[RGDfK], and of $2.17 \mathrm{mM}$ solution of cyclo[RGD(DMNPB)fK after light exposure for 26 and 90 minutes at $360 \mathrm{~nm}$ in PBS buffer (pH 7.4).

\section{Synthesis of DMNPB caged COOH-terminated silane and preparation and characterization of surface layers}

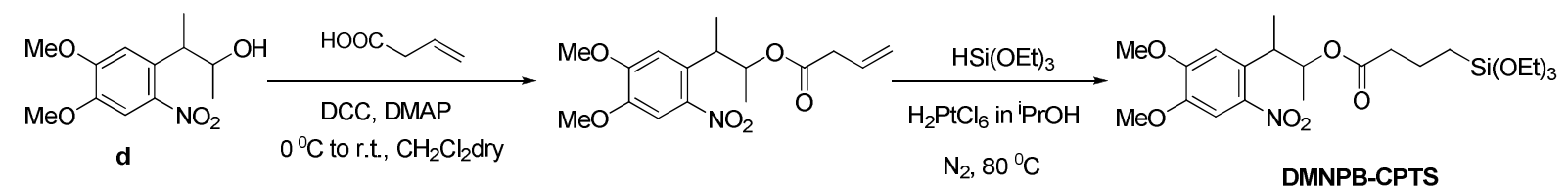

3-(4-5-dimethoxy-2-nitro-phenyl)-butan-2-yl-but-3-enoate: Butenoic acid (91 $\mu \mathrm{L}, 1.06$ mmol, 1 equiv.) was added to a solution of 3-(4-5-dimethoxy-2-nitro-phenyl)-butan-2-ol (270 $\mathrm{mg}, 1.06 \mathrm{mmol}, 1$ equiv.) in $15 \mathrm{ml}$ dry dichloromethane, which was cooled to $0{ }^{\circ} \mathrm{C}$. Then, the addition of DCC (220 mg, $1.06 \mathrm{mmol}, 1$ equiv.) dissolved in $\mathrm{CH}_{2} \mathrm{Cl}_{2}$ dry (10 mL) was followed dropwise for $10 \mathrm{~min}$. Finally, DMAP (10 mg, $85 \mu \mathrm{mol}, 0.08$ equiv.) was added to the solution. The reaction mixture was allowed to reach room temperature and after that the mixture was stirred overnight under Ar. Thin layer chromatography (TLC) indicated that the 
reaction was complete. The mixture was neutralized with $200 \mathrm{ml}$ saturated sodium bicarbonate solution and the aqueous layer was extracted with $50 \mathrm{ml}$ dichloromethane. The combined organic layers were washed with $100 \mathrm{ml}$ water and brine $(2 \times 100 \mathrm{~mL})$, dried over $\mathrm{MgSO}_{4}$, and the solvent was removed in vacuum. The residue was purified via column chromatography (silicagel, 3:1 hexane/ethyl acetate) to give $141 \mathrm{mg}$ (41\% yield) of the product.<smiles>C=CCC(=O)OC(I)C(I)c1cc(OC)c(OC)c(I)c1[N+](=O)[O-]</smiles>

${ }^{1} \mathrm{H}-\mathrm{NMR}\left(\mathrm{CDCl}_{3}, 250 \mathrm{MHz}\right) \delta(\mathrm{ppm}): 1.24-1.29\left(3 \mathrm{H}, \mathrm{m},-\mathrm{CH}_{3} \mathrm{f}\right) ; 1.30-1.34\left(3 \mathrm{H}, \mathrm{m},-\mathrm{CH}_{3} \mathrm{e}\right)$; 3.05-3.12 (2H, m, $\left.\mathrm{CH}_{2} \mathrm{c}\right) ; 3.78\left(1 \mathrm{H}, \mathrm{m}, \mathrm{CH}\right.$ g); $3.93\left(6 \mathrm{H}, \mathrm{m}, 2 \mathrm{xOCH}_{3} \mathrm{j}\right) ; 5.18\left(2 \mathrm{H}, \mathrm{m}, \mathrm{CH}_{2} \mathrm{a}\right)$; $5.63(1 \mathrm{H}, \mathrm{m}, \mathrm{CH}$ b); $6.84(1 \mathrm{H}, \mathrm{m}, \mathrm{Ar}-\mathrm{H}$ h); 7.37 (1H, m, Ar-H i).

\section{3-(4-5-dimethoxy-2-nitro-phenyl)-butan-2-yl-4-(triethoxysilyl)butanoate: 3-(4-5-} dimethoxy-2-nitro-phenyl)-butan-2-yl-but-3-enoate (140 mg, $0.43 \mathrm{mmol}, 1$ equiv.) and triethoxysilane $(0.8 \mathrm{~mL}, 4.30 \mathrm{mmol}, 10$ equiv.) were placed into a previously HMDSpassivated ${ }^{19} \mathrm{dry}$, round-bottomed flask and heated to $80^{\circ} \mathrm{C}$ under argon atmosphere. After addition of an isopropanolic $\mathrm{H}_{2} \mathrm{PtCl}_{6}$ solution $(22 \mu \mathrm{L}, 65 \mathrm{mM})$, the mixture was stirred for 3 hours at $80{ }^{\circ} \mathrm{C}$ and then allowed to cool. Excess of triethoxysilane was removed in vacuum, and the residue was taken up in dichloromethane and filtered through Celite500. The filtrate was concentrated under reduced pressure and determined to be the desired silane.<smiles>COc1cc(C(I)C(C)OC(=O)CC[CH-][Si]OC(C)I)c([N+](=O)[O-])c(I)c1OC</smiles>

${ }^{1} \mathrm{H}-\mathrm{NMR}\left(\mathrm{CDCl}_{3}, 250 \mathrm{MHz}\right) \delta(\mathrm{ppm}): 0.45-0.46\left(2 \mathrm{H}, \mathrm{m}, \mathrm{CH}_{2} \mathrm{a}\right) ; 1.22\left(9 \mathrm{H}, \mathrm{m}, 3 \mathrm{xCH}_{3} \mathrm{k}\right)$; $1.29\left(3 \mathrm{H}, \mathrm{m},-\mathrm{CH}_{3} \mathrm{f}\right) ; 1.32\left(3 \mathrm{H}, \mathrm{m},-\mathrm{CH}_{3} \mathrm{e}\right) ; 2.21\left(2 \mathrm{H}, \mathrm{m}, \mathrm{CH}_{2} \mathrm{~b}\right) ; 2.34\left(2 \mathrm{H}, \mathrm{m}, \mathrm{CH}_{2} \mathrm{c}\right) ; 3.60-$ $4.00\left(12 \mathrm{H}, \mathrm{m}, 3 \mathrm{xCH}_{2} 1,2 \mathrm{xOCH}_{3} \mathrm{j}\right) ; 4.24(1 \mathrm{H}, \mathrm{m}, \mathrm{CH} \mathrm{g}) ; 6.84(1 \mathrm{H}, \mathrm{m}, \mathrm{Ar}-\mathrm{H} \mathrm{h}) ; 7.37(1 \mathrm{H}, \mathrm{m}$, Ar-H i).

Surface Modification: A 1\% w/v solution of the photosensitive silane in THF with $30 \mu \mathrm{l}$ of 1 $\mathrm{N} \mathrm{NaOH}$ (aq.) was stirred during $30 \mathrm{~min}$. The solution was filtrated through a $0.2 \mu \mathrm{m}$ poresize PTFE filter in the reaction vessel, and clean substrates were immersed in it. After reaction, the substrates were rinsed with THF and Milli-Q water and baked for $1 \mathrm{~h}$ at $90{ }^{\circ} \mathrm{C}$ in a vacuum 
oven and stored in the dark. Experiments with increasing catalyst concentration and deposition times were performed to obtain layers with a maximum density of functional groups (as revealed by UV spectroscopy). Before further application, all substrates were sonicated in THF for 3 min, washed with Milli-Q water and dried under $\mathrm{N}_{2}$ stream.

\section{Characterisation of the density of chromophore}

The surface density of the chromophore, $\Gamma$ (molecs $\mathrm{cm}^{-2}$ ), can be estimated from the UV absorbance using $\Gamma=1 / 2\left[\mathrm{~A}_{\lambda} \varepsilon_{\lambda}^{-1} \mathrm{~N}_{\mathrm{A}}\right] \times 10^{-3}$, where $\mathrm{A}_{\lambda}$ is the absorbance of the surface layer at a given wavelength, $\varepsilon_{\lambda}$ is the molar extinction coefficient of the chromophore in solution at $\lambda$ $\left(\varepsilon_{346}=4100 \mathrm{M}^{-1} \mathrm{~cm}^{-1}, \lambda_{\max }=346 \mathrm{~nm}\right)$, and $\mathrm{N}_{\mathrm{A}}$ is Avogadro's number. ${ }^{20}$ The factor $1 / 2$ refers to the fact that the quartz slides are modified on both sides.

Photolysis experiments at the surface: Irradiation of the substrates was carried out using a LED (Edmund Optics) as monochromatic light source. The wavelength and irradiance used were $365 \mathrm{~nm}$ and $4.5 \mathrm{~mW} \mathrm{~cm}^{-2}$ respectively. After irradiation, substrates were sonicated in THF and rinsed with Milli-Q water before recording UV-Vis spectra.<smiles>COc1cc(C(C)C(O)OC(=O)/C=C(\C)c2cc([N+](=O)[O-])c(OC)cc2OC)c([N+](=O)[O-])cc1OC</smiles>

\section{QCM Experiments}




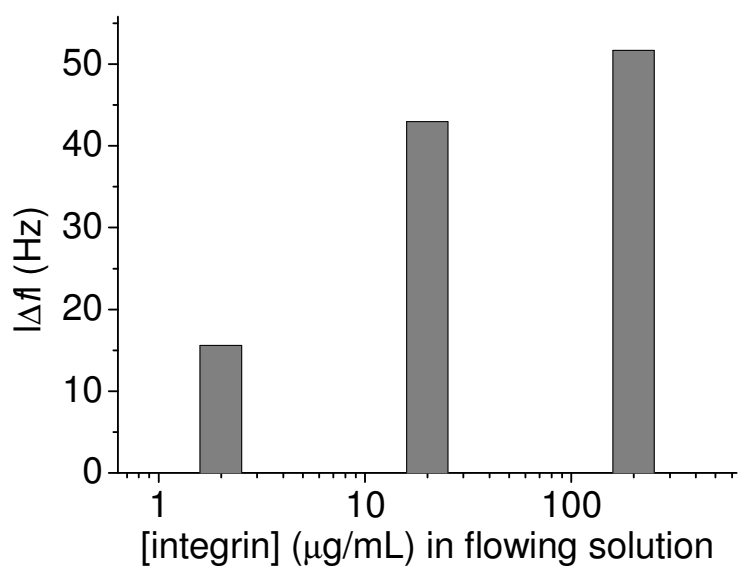

Figure D. QCM frequency shift corresponding to Integrin absorption onto a 4\% - $\mathrm{COOH}$ terminated SAM functionalized with cyclo[RGDfK]. The concentration of integrin solution was $2 \mu \mathrm{g} / \mathrm{mL}, 20 \mu \mathrm{g} / \mathrm{mL}$ and $200 \mu \mathrm{g} / \mathrm{mL}$.

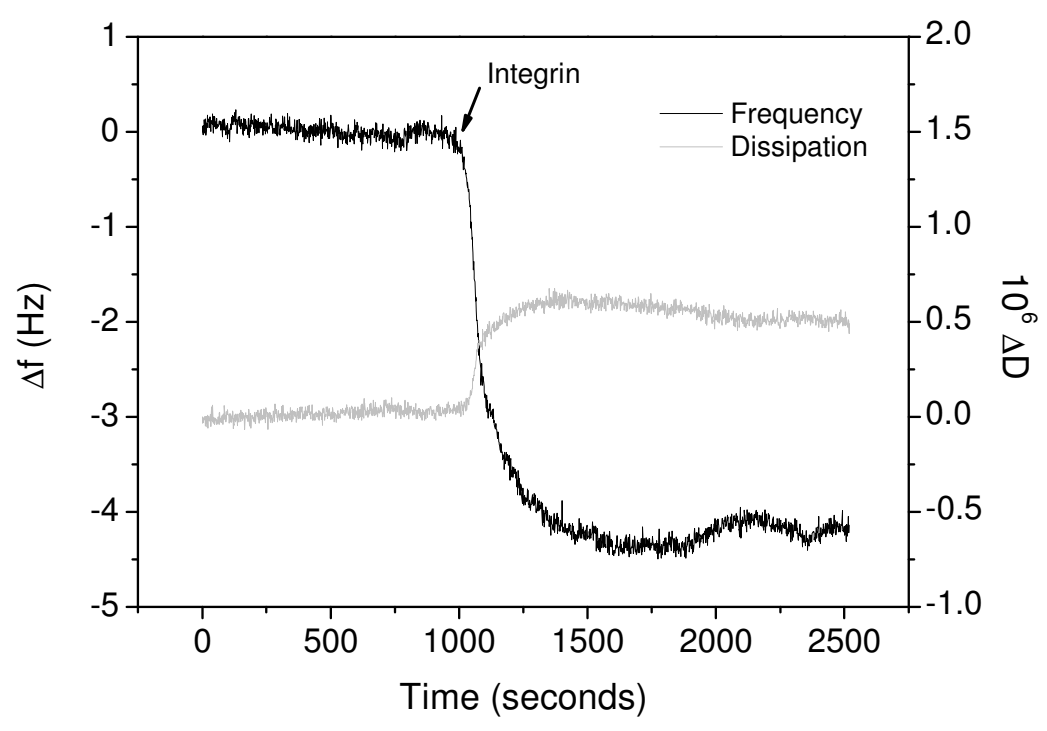

Figure E. Frequency shift and dissipation values observed in QCM-D experiments in the absence of $\mathrm{Mn}^{2+}$ and $\mathrm{Mg}^{2+}$ in the buffer solution upon integrin injection for substrates modified with a $1 \%-\mathrm{COOH}$ terminated SAM functionalized with cyclo(RGDfK).

\section{Cell images}




\section{HUVECs on cyclo[RGD(DMNPB)fK]}

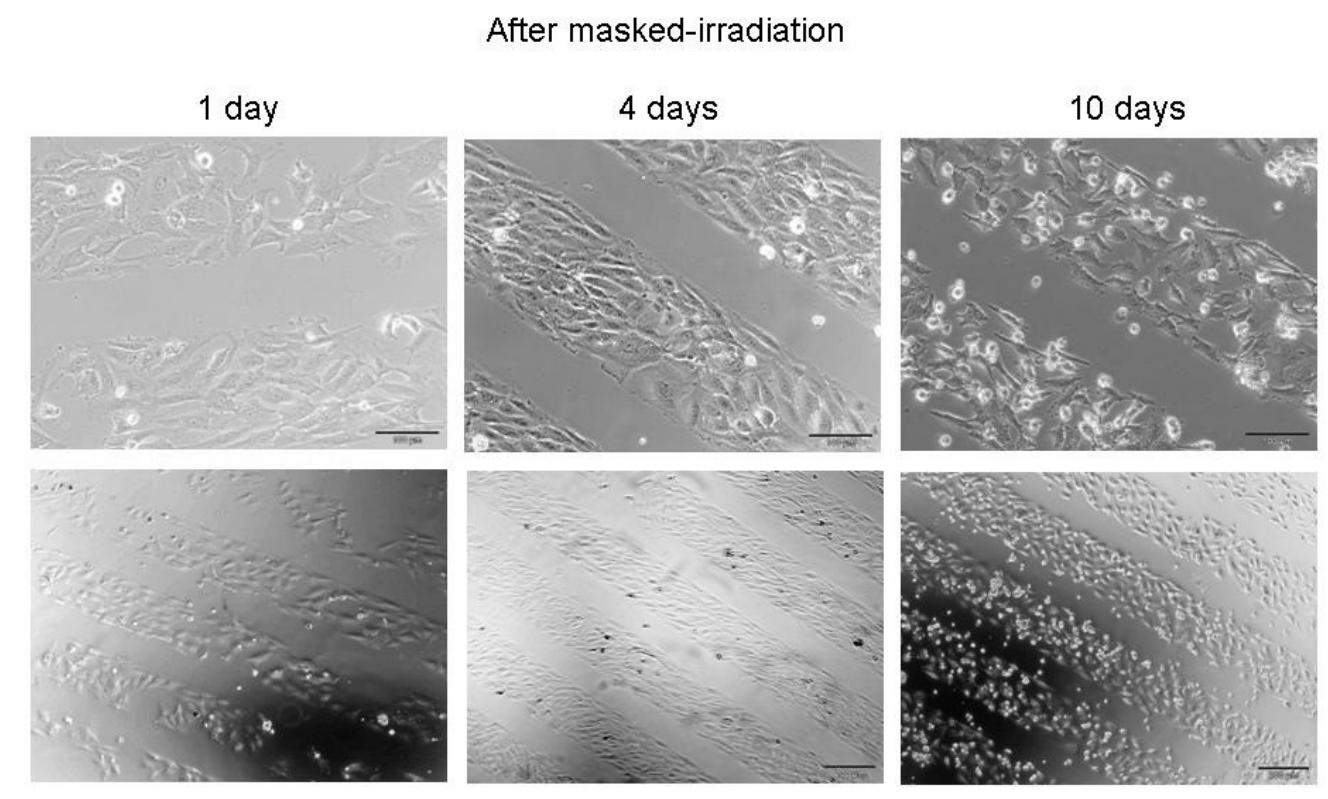

Figure F: HUVECs on cyclo[RGD(DMNPB)fK] modified substrates after masked irradiation after culture for 1-10 days.

\section{References}

(1) Okano, T.; Yamada, N.; Okuhara, M.; Sakai, H.; Sakurai, Y. Biomaterials 1995, 16, 297.

(2) (a) Yeo, W. S.; Hodneland, C. D.; Mrksich, M. Chembiochem 2001, 2, 590(b) Chan, E. W. L.; Park, S.; Yousaf, M. N. Angew Chem Int Edit 2008, 47, 6267(c) GuillaumeGentil, O.; Akiyama, Y.; Schuler, M.; Tang, C.; Textor, M.; Yamato, M.; Okano, T.; Voros, J. Adv Mater 2008, 20, 560.

(3) (a) Ohmuro-Matsuyama, Y.; Tatsu, Y. Angew Chem Int Edit 2008, 47, 7527(b) Petersen, S.; Alonso, J. M.; Specht, A.; Duodu, P.; Goeldner, M.; Del Campo, A. Angewandte Chemie International Edition 2008, 47, 3192(c) Muraoka, T.; Koh, C. Y.; Cui, H. G.; Stupp, S. I. Angew Chem Int Edit 2009, 48, 5946(d) Auernheimer, J.; Dahmen, C.; Hersel, U.; Bausch, A.; Kessler, H. J. Am. Chem. Soc. 2005, 127, 16107(e) Schutt, M.; Krupka, S. S.; Milbradt, A. G.; Deindl, S.; Sinner, E. K.; Oesterhelt, D.; Renner, C.; Moroder, L. Chem Biol 2003, 10, 487(f) Milbradt, A. G.; Loweneck, M.; Krupka, S. S.; Reif, M.; Sinner, E. K.; Moroder, L.; Renner, C. Biopolymers 2005, 77, 304(g) Dillmore, W. S.; Yousaf, M. N.; Mrksich, M. Langmuir 2004, 20, 7223(h) Nakanishi, J.; Kikichi, Y.; Inoue, S.; Yamaguchi, K.; Takarada, T.; Maeda, M. J. Am. Chem. Soc. 2007, 129, 6694.

(4) Guillame-Gentil, O.; Semenov, O.; Roca, A. S.; Groth, T.; Zahn, R.; Voros, J.; Zenobi-Wong, M. Adv Mater 2010, 22, 5443.

(5) Haubner, R.; Gratias, R.; Diefenbach, B.; Goodman, S. L.; Jonczyk, A.; Kessler, H. J. Am. Chem. Soc. 1996, 118, 7461.

(6) Pasparakis, G.; Manouras, T.; Selimis, A.; Vamvakaki, M.; Argitis, P. Angewandte Chemie International Edition 2011, 50, 4142. 
(7) Wirkner, M.; Alonso, J.; Maus, V.; Salierno, M.; Lee, T.; García, A.; del Campo, A. Adv Mater in press, DOI: 10.1002/adma.201100925.

(8) (a) Kirchhofer, D.; Gailit, J.; Ruoslahti, E.; Grzesiak, J.; Pierschbacher, M. D. The Journal of biological chemistry 1990, 265, 18525(b) Ruoslahti, E.; Pierschbacher, M. D. Science 1987, 238.

(9) San Miguel-Arnanz, V.; Bochet, C. G.; Del Campo, A. J. Am. Chem. Soc. 2011, 133, 5380 .

(10) Unger, R. E.; Krump-Konvalinkova, V.; Peters, K.; Kirkpatrick, C. J. Microvasc Res 2002, 64, 384.

(11) Rochet, N.; Dubousset, J.; Mazeau, C.; Zanghellini, E.; Farges, M. F.; de Novion, H. S.; Chompret, A.; Delpech, B.; Cattan, N.; Frenay, M.; Gioanni, J. Int J Cancer 1999, 82, 282.

(12) Hayflick, L. in Kruse, P. F., Jr.; Patterson, M. R., Jr., eds. Tissue culture: methods and application 1973, New York: Academic Press, 220.

(13) Alvarez, M.; Alonso, J. M.; Filevich, O.; Bhagawati, M.; Etchenique, R.; Piehler, J.; del Campo, A. Langmuir 2011, 27, 2789.

(14) (a) Specht, A.; Thomann, J. S.; Alarcon, K.; Wittayanan, W.; Ogden, D.; Furuta, T.; Kurakawa, T.; Goeldner, M. Chembiochem 2006, 7, 1690(b) Walbert, S.; Pfleiderer, W.; Steiner, U. E. Helv. Chim. Acta 2001, 84, 1601.

(15) Love, J. C.; Estroff, L. A.; Kriebel, J. K.; Nuzzo, R. G.; Whitesides, G. M. Chem Rev 2005, 105, 1103.

(16) Petrie, T. A.; Capadona, J. R.; Reyes, C. D.; Garcia, A. J. Biomaterials 2006, 27, 5459.

(17) (a) Nakayama, Y.; Matsuda, T. Macromolecules 1999, 32, 5405(b) Heeb, R.; Bielecki, R. M.; Lee, S.; Spencer, N. D. Macromolecules 2009, 42, 9124.

(18) (a) Pierschbacher, M. D.; Ruoslahti, E. Nature 1984, 309, 30(b) Doolittle, R. F.; Watt, K. W. K.; Cottrell, B. A.; Strong, D. D.; Riley, M. Nature 1979, 280, 464(c) Suzuki, S.; Oldberg, A.; Hayman, E. G.; Pierschbacher, M. D.; Ruoslahti, E. Embo J 1985, 4, 2519(d) Grant, D. S.; Tashiro, K. I.; Segulreal, B.; Yamada, Y.; Martin, G. R.; Kleinman, H. K. Cell 1989, 58, 933.

(19) del Campo, A.; Boos, D.; Spiess, H. W.; Jonas, U. Angew Chem Int Edit 2005, 44, 4707.

(20) Bramblett, A. L.; Boeckl, M. S.; Hauch, K. D.; Ratner, B. D.; Sasaki, T.; Rogers, J. W. Surface and Interface Analysis 2002, 33, 506. 